\title{
Old-new Problems with Housing after 27 Years of Transformation Questions Regarding the Sociology of Dwelling
}

\author{
Grażyna Woroniecka \\ Center of Sociology of Dwelling, Institute of Applied Social Sciences, University of Warsaw, Poland
}

Copyright $(2016$ by authors, all rights reserved. Authors agree that this article remains permanently open access under the terms of the Creative Commons Attribution License 4.0 International License

\begin{abstract}
The article tackles the issue of the field of research into the contemporary sociology of dwelling. In the light of extremely liberal housing policy based on the assumption of housing needs being financed with the capital of the individual buyers due to their purchasing capabilities (via loans), one may acknowledge that dwelling culture has undergone significant change. Though slowly and with obstacles, market demand is causing a certain differentiation in what is available, and this is accompanied by equally sluggish processes in the reshaping of buyers' expectations. The evolving demographic structure, changing customs, increased mobility (compared to the Polish People's Republic) and migration processes comprise a new picture of models, practices and preferences related to one's dwelling. The developing rental market is conducive for the adjustment of supply to these preferences, though slowly and despite unfavourable regulations, although there is still a long way to go before it becomes fully functional. Housing policies are doing little to meet the real expectations, focusing only on the issue of financing social housing. The sociology of dwelling faces the task of compiling a description of cultural change that could become the basis for constructing micro- and mezzohousing policies based on the self-reference concept of the buyers' interest, thus showing a greater degree of adequacy and lower level of ideologisation.
\end{abstract}

Keywords Liberal Housing Policy, Capital, Rent, Diversification of Dwelling Practices, The Sociology of Dwelling

\section{Introduction}

The balance of gains and losses in social and economic terms since 1989 continues to this day to provoke constant controversy, providing sustenance for political disputes especially during election campaigns. Symbolically this balance is apparently deep in the red, as we are losing identity (however it is understood). In the economic sense, then on the one hand areas of poverty previously diligently hidden in the rhetoric of equality and rationed consumption are coming to light, while on the other there is a growing throng of 'middle' consumers approaching (though slowly) the average standard in the less affluent countries of the 'old' European Union. Any attempt at making a comprehensive appraisal must give rise to doubt, since it derives from a specific perspective embroiled in the valuing of the person making it. That is why in this paper I focus on a single issue: the availability of dwellings. Back in the Polish People's Republic this problem was extremely sensitive, and successive 'five-year plans' notched up failures, unable to satisfy demand while those in line had to queue for periods exceeding 20 years. From the point of view of biographical and family plans this was obviously absurd, and as such the situation triggered layers of brutality and ingenuity to which candidate-tenants would revert.

An interesting point is that, regardless of the socialeconomic system, there is a similar housing shortage today: in 1989 the deficit of dwellings was estimated to be 1.3 million, compared to $1.6 \mathrm{~m}$ in 2005 (Matusik, n/a: 2), and $1.3 \mathrm{~m}$ in 2014 (Housing Construction... 2014). The temporary growth in the number of dwellings under construction following Poland's accession to the European Union slowed down as a result of the worldwide economic crisis that struck the real estate market first of all. Changes in the system of distribution meant, in turn, that calculations were no longer based on the number of dwellings built, but on the number 'put into use', or - to put it in more contemporary though less professional terms - sold.

This lingual anachronism in itself reveals practically in full the market character of current housing policy. Just a decade ago the phrase 'to receive a flat', carried over from the previous economic system, was still in colloquial use (Woroniecka 2004: 323). Today one talks of buying, of accepting or commissioning (in the technical sense). The change in rules has taken hold in colloquial thinking. And 
indeed, the share that owners (physical persons) had in multi-dwelling buildings in the year 2014 was, depending on the province, from 93.1 to $98.9 \%$, compared to less than 2\% in 1989 (Housing Economy, GUS 2014).

This change has taken place over the last 26 years in an economic sense, but the social and cultural context in which the transformation of the economics of dwelling took place has also changed. The said transformation has been a result of such factors as the low birth rate (1.3 since 1989), overrepresentation of elderly and frequently single people in the population, new models of family life (brief cohabitation, entering marriage at an older age, low fertility rate), the diversification of lifestyles (frequently influenced by global trends), mobility (related to work or studies), work performed at home, and entering one's place of living into the space of digital communication (Morley 2011) - all processes conducive to further deconstruction of the notion of the traditional 'home'. In addition there is an issue barely noticed in the context of the distribution of dwellings, but of growing significance: namely that of immigrants with their cultural baggage.

\section{Beyond Theoretical Framework}

Work done today in the area of the sociology of dwellings can only refer to predecessors' achievements to a small degree. Sociology today reaches less often for socalled 'hard data', orienting its exploration rather towards the area of everyday interpretations, which requires a different set of conceptual instruments. The censorship requirement disallowing analyses in categories of class has vanished, its place taken by the demand for political correctness, often no less bothersome in analytical terms. Data regarding the numbers of dwellings commissioned each year conceals other content: this is not reporting on the effectiveness of state-owned factories producing homes, but concrete and highly diversified economic data speaking of the condition of the investors and the scales and trends in demand. Alongside the planners and contractors many new participants now have their say in the debate regarding how to live: people representing urban movements, alternative sub-cultures focused on ecological values, groups involved in the revitalisation of specific urban areas, and civic movements demanding rights to urban spaces; on the other hand cities have suddenly become covered in corporate office buildings occupying the costliest investments sites, while public space has become the subject of disputes and horse-trading on a scale unseen since the outbreak of World War II.

In this situation studies investigating housing must begin by formulating new questions. These will be questions about the subject of changes and projects, about the beneficiaries of housing policies, but also about the aesthetic, functional, cultural, national, ethnic or class character of new housing. It is also essential that the list of new research questions include the consequences of income inequality and the growing material differences between social groups. In regard to home furnishing they will seem so clear-cut as in the Polish People's Republic (Jewdokimow 2011: 129-164), but they often prove to be a factor decisive in regard to the chances an individual has for any dwelling of their own whatsoever, which they simply have to buy.

It is not difficult to understand the initiators behind the extremely liberal housing policy. In 1989 the Polish economy lacked capital not only for constructing but also for properly maintaining the existing housing stock. This was due on the one hand to costly technologies, and on the other - building regulations holding back the introduction of cheaper, innovative solutions. It was also a result of the bureaucratic structure of housing management, as well as the specific perception of the dwellings' end-users, whose actual needs were of no interest to the decision-takers, and who were persuaded that they should not voice any specific requirements stepping beyond the generally accepted standard finally delivered after - very often - many years of waiting. In this paper I consider the consequences of such an extremely market-oriented policy from the point of view of its addressee, only taking other factors into consideration in regard to the context of the changes that took place in the realm of culture.

\section{Materials \& Results}

\subsection{Property at any Price}

Due to the shortage of capital, the implementation of housing policy meant reaching for sources of finance that could not be set in motion in any other way: to the individual investor highly interested in obtaining a dwelling. Public and local authority funds played but a marginal role; the cited index of over $90 \%$ of home ownership was achieved with the aid of private capital, capital which there was not. The relatively low level of income was not a major obstacle as back in the nineties a relatively high percentage of the employed had job contracts. With bank capital being allowed into the country, two goals were achieved at the same time by leaving housing construction to the market forces: Poland's attractiveness for banks was raised by providing them with a pool of relatively stable customers, and the strain was eased on public finances, in particular local government finances. For the average customer this meant that they had to learn how to live with a bank loan.

The first two years of implementation of such policy were marked by regular scandals related to developers' investments. Customers, who were made 'investors' without being asked, were in no way prepared in terms of the appropriate skills required for this role. Construction based on the investors' money had to result in regulations restricting the developers' liberty in managing the funds they were entrusted with; such regulations are still being drawn up and improved in relation to the variable market 
conditions, but their investigation is not a part of this particular study. I should only add that the area showing most resistance here is cooperative law, where there continue to be provisions allowing the boards of housing cooperatives to mortgage so-called 'ownership' dwellings (a characteristic term meaning ownership differently) without the consent or even the knowledge of their owners (for a broader treatment of the specifics of housing cooperatives, see Peisert 2009).

As with the construction costs, the costs of building maintenance were also dumped on individuals and households. The act on the ownership of premises, dated 24 June 1994, brought an end to the process of unwanted enfranchisement involving the sale of dwellings by communes, places of work, and - to a lesser degree housing cooperatives to their current tenants for a fraction of their price. Tempted by the low price, they suddenly discovered themselves burdened with the costs of renovation for what were frequently decapitalised postcouncil buildings. I described the process of learning the role of owner in such a manner in the book Działanie polityczne (Woroniecka 2001); the situation was made more dramatic by the fact that local authority bureaucracy reverted to all possible means (including manipulation and intimidation) in order to retain their right to administer the resources thus enfranchised, as it constituted the economic basis of its existence. Housing cooperatives in turn functioned as an object of political horse-trading, and as a result in later years they applied a broad variety of rates for the purchasing of dwellings. This placed their tenants in a situation of uncertainty, and gave rise to much tension between the beneficiaries of populist solutions practically giving away these premises for free, and those who had bought them earlier for a certain percentage of their market value.

This synthetic overview of the stages of housing policy may, of course, be broadened to encompass the problem of reprivatisation of tenement buildings with tenants, or the sale of inhabited company buildings to private and institutional investors, but this would not contribute anything new to the aspect we are interested in. This is because all strategies used in the feverish enfranchisement share a common denominator: introduced suddenly and chaotically, not preceded by any social campaigns, with no program differentiating the social groups they were addressed to and even with no attempt at ascertaining their social and cultural characteristics, their effects were mixed. In an economic sense their result should be acknowledged as positive: room appeared on the market for the big players - for bank capital, via which the economy gains (a claim by the economists for which I have to take a leap of faith). Many jobs were created, and small business sprung up specialising in the management of real estate comprising individual shares - frequently counted in fractions of a percentage. As for the social costs, the situation is not so unequivocal, and estimating them is complicated further by the absence of criteria differentiating in social and cultural terms the categories of the people affected. An increase in the cost-intensive nature of dwellings is certainly common to all. It is not only the purchase, but also the handling of the loan and the increased costs of managing - and due to the lack of knowledge regarding building technologies or organisation of the construction process, plus a lack of skills in reading contracts with banks or in professional management, then all the stages related to a dwelling are burdened with a kind of mark-up. Legal and administrative regulations are also conducive to the maintaining of numerous intermediaries; the same regulations pass the entire risk on to the individual buyer.

The 27 years that have passed since 1989 have seen the creation of a housing market, but it continues to be a customer-unfriendly market, unintelligible, with little to offer and disinclined to apply negotiating procedures. Data regarding the scale of the housing deficit also reveals this market to be ineffective. The deficit in the number of dwellings is at the same level as it was in the economy of real socialism, despite the exhaustion of highly-scattered micro-capital for the coming 40 years (the maximum period for which mortgage loans are taken out), even though companies building housing are today administering entire blocks of unsold flats. Instead of solving the problem of housing demand, the unseen hand of the market has only brought about the production of dwellings. At the same time it has pauperised throngs of working people, and brought an element of perpetual uncertainty into their everyday lives.

Positive sides to such a situation also exist, quite naturally. Its beneficiaries are those whose priority is mobility, with the housing situation adjusting flexibly to changing needs. Sale and purchase transactions can be carried out practically overnight, despite the high transaction costs, as long as one is able to bear these additional costs. When the price for $1 \mathrm{~m} 2$ of dwelling space in large cities significantly exceeds the average monthly wage, then there are few such beneficiaries. The rest either have to say goodbye to their housing prospects (more about renting in a moment), or have become tied to their debtburdened dwellings for many years to come, with all the consequences as I shall sketch out somewhat later.

The way in which housing was managed in the Polish People's Republic allowed for little individual ownership. The complicated system of allocations back then has been described in such depth in literature on the topic (see, for example, Jarosz 2010) that I will not go into details here. There is almost nothing left of that system today, other than a particularly suspicious attitude towards rental. This suspicion, a consequence of rational interpretation of the restrictive regulations from that period (Jarosz 2010: 299306), was one of the factors that helped in the public legitimisation of establishing an individualist-market housing policy post 1989. It also justified marginalisation of the problem with the aid of the childish belief that the market, after some time, would itself have such a regulative effect that the extortionate prices of private renting would fall, the owners of unoccupied dwellings would cease to be 
afraid of rendering them available, and the difficult-toestimate reserve of dwellings for those unable to secure a market foothold would be revealed. However, this happened to less of a degree than expected by the optimistic assumptions. Following the enfranchisement of the former tenants of council and company housing, it has proved once again essential to face the problem of social housing.

The first step taken in this direction was, as a consequence, liberal in character: the nineteen-nineties saw the introduction of tax relief (now abolished) for private investors building dwellings for rent. Once again this was meant to resolve two problems at once: to syphon surpluses in income - growing quickly but unevenly - from the market, and to use this for solving a social problem. And once again the calculations proved too optimistic. The next project, this time more of a hybrid nature, began in 1996. Social Housing Associations (TBS - essentially very similar to the housing cooperatives still operating on inconsistent principles) used significant financial input from their future residents, while at the same time enjoying preferential bank loans. TBS dwellings were intended to remain tenant flats with no option for resale to their tenants. The Housing Fund, an institution intermediating in the transfer of public funds for social housing, was disbanded in 2009, and the provision functioned until 2011 (Sprzedaż mieszkań... 2015), following which precedent-based cases of 'transformation to ownership' were increasingly common. Currently, following a period of inactivity, the TBS program is renewing its building operations, and is practically the only program (apart from the trace presence of cooperative operations) for constructing homes for rent.

The above brief review of the priorities in housing policy post 1989 reveals the domestic 'housing issue' as an area replete with tensions, brimming with potential social conflict, legitimising economic violence and releasing unimaginable resources of mutual distrust. And what is most striking - that not only are no cultural mechanisms honoured here, ones thanks to which people organise their home space in varied manners, but even the cultural capital of models of dwelling has undergone total, officially programmed devastation. A dwelling, just like a plasma television, has become a luxury product, one that one has to possess whatever the cost, and one simply cannot have one worse than the neighbour has.

\subsection{Standard Offer and Range of Adaptations}

One of the topoi that makes housing policy a tool for the production of constantly too small a number of an inadequate 'product' is one I have termed the family topos (Woroniecka 2004: 322-3). In the cultural and demographic realities this is the programming of dwellings for around 20 to 30 years of one's life, the years necessary for a couple to have offspring and for the said offspring to be capable of achieving independence. With the rising age at which procreative decisions are taken, and the still-growing average life expectancy, this is a strikingly erroneous assumption. Accepting that on average individuals express a readiness to live independently when around twenty years old, while they begin migration related to study or work away from their hitherto home locality somewhat earlier, the planning of a 'shared nest' as the fundamental form of living is fighting against the facts. Let us add to this today's widespread practice of years of cohabitation by childless couples, let us add those who are working and living on their own, or couples whose children are ready to leave home, widows, widowers, and finally those with an increasing degree of frailty due to illness or old age. Each of these sets has different spatial needs, yet they are all being forced to fit into 'family-designed' dwellings. The resultant situation is reflected well in a humorous illustration in which unshaven 40-year-olds are sitting at the bar and drinking beer in contemplation; one says to the other: "It would be great to live in Berlin, but my parents won't agree to move..."

Young people, whose mobility is a result of their educational needs and their search for a job, are making do with dormitories (of limited supply and tying the tenant closely to the institution) or renting. Yet the private market has not come up with anything taking the specific nature of their spatial needs into account. As such, they are renting dwellings designed 'for the family', and because of the price this frequently means renting in groups. This is setting in motion processes psychologically and socially unfavourable, described in the pioneering book by Magdalena Łukasiuk and Marcin Jewdokimow: Niedom. Socjologiczna monografia mieszkań migracyjnych [A NonHome. Sociological Monograph of Migration Apartments] (2012). Shared with random cotenants, and not tailored to their new functions, these dwellings - note the authors impose such organisation of living that contradicts its fundamental determinants: making it impossible to achieve a state of unreflective usage of domesticated, safe and intimate space in which one's sense of security results from its 'embodiment' (p. 142).

In dwellings referred to in the cited book as 'migration' homes, their residents split the space into zones in a manner different to that in a 'family' dwelling. The kinds of space there are mine, yours, shared and nobody's (p. 149), i.e. the same types found in student dormitories and halls of residence. However, they have no regular administrative staff, which lowers the costs of upkeep. Neither are there any guidelines regarding the dwellings' standard - the owners usually only set conditions regarding usage of the provided fittings, although even this is sufficient for the tenants to constantly have the feeling that they are living 'in somebody's house' - a theme that appears frequently in interviews with tenants.

Because of young adults' economic weakness, developers are seeking a source of capital for purchasing their products among elderly citizens (Wielgo 2015: 22). They are attempting to meet the expectations of older customers by offering smaller dwellings, cheaper on upkeep, 
but with added convenience, e.g. wider doors and corridors that a wheelchair can fit through. Such perception is severely simplifying the needs of the potential buyer, which only in the future will probably once again be verified by the 'invisible hand' of the market. Such a mindset reveals on the one hand the sluggishness and enforced character of renouncing the standard, while on the other hand it is potentially stimulating for the market of existing housing stock, since the buyers already live somewhere and will most probably put their previous dwelling up for sale or rent. The liberal project evidently proves that it is far from perfection: the domestic market for dwellings, without capital, answers very slowly and clumsily to consumers' needs.

By dictating the technology and the style, developers' investments make no distinctions between potential buyers. They use the price to dazzle, and have come up with different versions of the standard, but these do not reflect cultural or sub-cultural specifics to even the slightest degree. Without a diagnosis of the demand, which could for example be provided by housing sociology, they are filling urban and suburban space with investments not designed for anybody in particular, entirely as if there were no social groups in Poland sharing the standards of labour or rural culture, cultural minorities (Tatar, Vietnamese), the subculture of artistic bohemia or those interested in the proximity of large extended families. Such juxtaposition, deliberately random, shows the multi-faceted intersecting of criteria in the forming of identity, characteristic of contemporary culture and usually temporary to some degree or other, or at least potentially susceptible to change at relatively low costs. The market's distribution of housing space does not work in the 'world in motion'; focused directly on short-term profit, developers are not interested in 'experiments' with lighter, environmentally friendly and innovative technologies: they employ as cheaply as possible in order to construct standard buildings with the greatest chance of selling. The semantics in developers' construction unequivocally reveals the desired addressee: a family with two children, with well-established jobs and two cars, each busy at their computer in the evening. It is interesting to note that interior décor magazines do not relate to such a target, addressing their interior styling proposals above all to the individual investor, for whom the family might just be the background - needing to be discretely situated so as not to ruin the design's coherence (Rancew - Sikora 2007). Phrasing it using the media's rhetoric, the developer's dream customer is a 'lemming' ${ }^{1}$ focused on making money.

The image of the lemming in the press is not a favourable one. Derided and belittled, he proved the main pillar supporting the project for rebuilding the free-market economy in Poland. Today's critical discussion regarding

1 A word used pejoratively in Poland, the term coined by right-wing blogs in the early 21 st century, describing people blindly following the government and mainstream media with a dislike for more conservative parties and media; generally young, urban, and well-educated. the middle class, the capital of solidarity and public trust, is a symptom of the political floodlight shifting beyond the borders of the free market as narrowly understood. The ethos highlighted in this discussion, and which critics are so concerned about, is above all one of distrust and a mind-set of barriers isolating oneself from the social environment. And once again, despite numerous attempts at questioning the trickle down model, its functioning is strikingly visible: it began with the construction of housing estates of 'higher' standard surrounded by fences, following which tenants' associations of much more modest means in terms of finance and land also began fencing themselves off, even leading to such absurd situations where the fences around one blocked passage for other vehicles or even pedestrians (for more on gated communities, see Gądecki 2009, Cesarski 2010). The fact is that the market's housing policy matches this ethos, building a line of division between the buyers (regardless of the costs) and the rest, i.e. those either unable or unwilling to let themselves be chained by the overblown costs.

\section{Discussion}

This housing monoculture is being broken by those disappointed in their experience with at-any-cost ownership. Young families are beginning to turn away from 'apartments' and look for flats to rent, homes that will be better suited to their budgets and their plans regarding procreation. Though to a small degree, this is bringing about a certain revival in the demand for flats in older blocks (Tomczuk 2015: 38-40). Rented, and relatively small, they are filling the existing gap in demand on new rules. The growing supply of small flats and their relative diversity satisfies both the economic situation of young tenants and their need for mobility. The costs of the transfer of ownership are significant; the costs of changing cities and renting a different flat - low.

However, this tendency - though noticeable - is of marginal significance on a country-wide scale. It conforms to the conventions of lifestyle and fashion, but changes little in regard to the shortcomings of housing policy. In the economic balance, the externalising of costs onto the residents will pay off for as long as there is no change in conservative technological thinking, in the policy for managing land for development, in the dysfunctional way of thinking about habitat infrastructure and in regulations regarding the renting of dwellings. The trend of building 'for years' characteristic of non-affluent societies is visible in both multi-dwelling and single-dwelling building construction. The sale of houses built using technology based on timber and other lighter materials is limited to a niche in the construction of detached houses, and is of marginal importance, while the choice is meagre. Expensive construction means that investment in housing for rent is unprofitable for private investors, while restrictions in rent additionally discourage communes from investing. 
Regulations protecting tenants act like a scarecrow to those with dwellings to offer, while the cultural judgments of 'billet-lodging' mentality additionally fuel mutual distrust between parties to such transactions. There is also a shortage of infrastructure related to rental and lowering the risk borne by the parties: insurance on the non-payment of rent by tenants, warehouses for storing surplus items, or effective forms of trade in used real estate, etc., i.e. options conducive to mobility. On the other hand there is a growing number of rental agencies, leading to the conclusion about the first stage of creating a rental culture. In the current situation, the renting out of dwellings means risks for the owners, resulting from legislation and deficiencies in the institutional context. Thought on housing policy usually ignores these issues, focusing on the economic aspects (construction) and the protection of tenants' rights, instead of focusing on reorganisation of factors that would reduce the risk and increase the attractiveness of the supply.

Especially as the supply of flats for rent is encountering multiple restrictions, among which - apart from those mentioned above - the cultural stratification issue is not devoid of importance. Following waves of nationalisation, communalisation and forced billeting, there is a shortage of properties appearing naturally on the rental market as a result of the passage of generations. The culture of renting, as well as customs regulating the scope of interference and liberty in the space of a dwelling, have fallen into oblivion. The conservative policy of service providers is not facilitating a stimulation in rentals either; they offer few options for pre-paid charges (e.g. electricity metres taking magnetic cards), and the costs of converting homes' existing metering devices are also high.

In general the problem of dwellings for rent breaks down into a few mutually blocking themes. In the language of social policy it has been connected with subsidising poorer families from public funds; hence the subject of social building and the fundamental conflict of interests with the extremely liberal paradigm. An additional obstacle lies in this topic being set within equality rhetoric and tenants' rights, which is significantly stifling practical measures. Pragmatics inclines one to use the so-called 'minimum standard' in social building (Jewdokimow 2011: 182), which is perceived unfavourably by society and sets in motion a flood of concern regarding the stigmatisation of future tenants. The negative consequences of relative deprivation resulting from application of the 'minimum standard' would embrace the psychological sphere, while also harming biological health (ibid.). The interesting thing is that applying technology options enabling the shutting off of unpaid services is interpreted as an "extreme form of coercion to pay bills" (ibid.) and is looked upon very unfavourably.

Alongside this theme, and beyond the official discourse, research has revealed the absence of available dwellings tailored to customers' spatial needs as well as shortcomings in rental culture, due to which the provisions of the Civil Code (applicable in these contracts) have no cultural complement. This situation generates numerous tensions, due to which rental is perceived by both tenants and owners as a difficult, risky and frequently annoying venture.

And finally the 'luxury' niche, the presence of which is only noted in studies, although those using it are not reporting any distinctive problems or demands. Here liberal policy has been a total success: it has eliminated the hitherto barriers, and freed the potential in execution.

\section{Conclusions}

If one were to be tempted to determine the changes emerging in dwelling culture under the influence of over a quarter a century of liberal housing policy, there would most probably be a list of preliminary observations requiring direction to be given to more precise research. At its top is the change in thinking about one's home, one's dwelling; today it is not a dwelling that one has to 'get', but a loan. Hence also the lower expectations in terms of the floor area of the dwelling one are looking for, as this is determined on the basis of purchasing ability. Buyers largely proceed in keeping with strategies appropriate for the consumption of other relatively costly material goods, making their choice while particularly taking into account the standards of the cultural context. This would explain the relative aversion towards buildings constructed using technology other than masonry, or expectations regarding the issue of the 'functionality' of the dwellings wanted (which in turn producers respond to, providing products as typical as possible, i.e. those chosen the most often). The preferred transactions leave no room for innovation, for artistic experiment or temporariness. In other words, consumers' conservatism and imitative tendencies also show themselves in the interior décor (Jewdokimow 2011: 165-209.).

An interesting development is the raising of the issue of ways of living by immigrants with cultural differences sufficiently significant that they might result in transformation of the habitats ${ }^{2}$. The topic of migrants and their specific accommodational needs will presumably be resurfacing to an ever greater degree, as happened in other countries with a significant immigrant population (Kumar 2007: 258-261). This will probably lead to two further issues making a return to social debate: policy regarding the settling of the Roma, and the problem of social housing (long-term or temporary, granted conditionally or unconditionally, with or without a financial contribution by the tenants, of 'minimum' or 'universal' standard, etc., etc.). Discussions on these topics, largely ideological and

2 The seminar on multicultural neighbourhood organised on 25 June 2015 by the Royal Netherlands Embassy as part of the EU project 'My Home Your Home? Research on threats to integration of foreigners in Poland' testifies to the research interest in this issue. The seminar saw a comparison of Dutch researchers' experience with the findings of Polish research conducted in Raszyn and Legionowo, both home to large concentrations of Vietnamese. 
involving axiological dimensions of culture, are proceeding in parallel with practices, although not always are the latter a consequence of the former. Integration or segregation - a problem significant to the residents of gated housing estates, including estates of detached houses being built in suburban villages alongside the existing rural fabric; own or rented, one always with the option of passing down to subsequent generations, or cheap and flimsy, so that it is easy to exchange, to leave and find a new one; hidden behind a barrier of gates and locks and close-circuit television, or accessible to the eyes of online cameras the residents turn on in their bedrooms and bathrooms - these and other dilemmas are coming together into an ever more complicated pattern of diversity in living practices, a pattern superimposed on the hard economic divisions and the material constancy of concrete. Researchers of ways of living now have the very rewarding task of scrupulously documenting the variability and flexibility of living practices, which are consistently and persistently splitting asunder the spaces and forms designed for them, so as to determine the dynamic constellations of practical ways of use, and to transform the material into the social and tamed.

\section{REFERENCES}

[1] Beck Ulrich (2002) Społeczeństwo ryzyka. W drodze do innej nowoczesności [Risk Society: Towards a New Modernity]. Warsaw: Scholar.

[2] Housing Construction - GUS [Central Statistical Office] tables, www.stat.gov.pl/obszary-tematyczne/budownictwomieszkaniowe-w-okresie-i-xii-2015,html, accessed 10 May 2015.

[3] Cesarski Maciej (2010) Refleksje na temat książki Jacka Gądeckiego o osiedlach grodzonych w Polsce [Reflection on the Margin of Jacek Gadecki's Book about the Housing Estates Fenced Off in Poland], "Człowiek i środowisko" 34 (1-2) pp. 43-58.

[4] Gądecki Jacek (2009) Za murami. Osiedla grodzone w Polsce - analiza dyskursu. Wrocław: Uwr.

[5] Housing Economy, GUS [Central Statistical Office] 2014, www.state.gov.pl/obszary tematyczne/gospodarkamieszkaniowa-2014-tablice-przegladowe, accessed 10 May 2015.
[6] Jacyno Małgorzata (2007) Mieszkanie i “moralna architektura" kultury indywidualizmu (in: ) G.Woroniecka (ed.) "Co znaczy mieszkać? Szkice antropologiczne", TRIO, Warsaw, pp. 31-46.

[7] Jarosz Dariusz (2010) Mieszkanie się należy. Studium z peerelowskich praktyk społecznych Warsaw: Oficyna Wydawnicza ASPRA-JR.

[8] Jewdokimow Marcin (2011) Zmiany społecznych praktyk zamieszkiwania. Warsaw: UKSW.

[9] Kumar Sandeep (2007) Adaptacje domów mieszkalnych imograntów hinduskich w Toronto [Housing Adaptations: A Study of Asian Indian Immigrant Homes in Toronto] (in: ) G.Woroniecka (ed.) "Co znaczy mieszkać? Szkice antropologiczne”, TRIO, Warsaw, pp. 249-265.

[10] Łukasiuk Magdalena, Jewdokimow Marcin (2012) Niedom. Socjologiczna monografia mieszkań migracyjnych [A NonHome. Sociological Monograph of Migration Apartments]. Warsaw: Wydawnictwo akademickie ŻAK.

[11] Matusik Adam (2015) Boom mieszkaniowy w Polsce ostateczne rozwiązanie kwestii społecznej? www.spolecznieodpowiedzialni/pl/files, brw., accessed 10 May 2015.

[12] Morley David (2011) Przestrzenie domu. Media, mobilnośc i tożsamość [Home Territories: Media, Mobility and Identity]. Warsaw: Wyd. Narodowe Centrum Kultury.

[13] Peisert Arkadiusz (2009) Spółdzielnie mieszkaniowe: pomiedzy wspólnota a alienacją. Warsaw: WUW.

[14] Rancew- Sikora Dorota (2007) Dom estetyczny jako dom indywidualny (in:) G.Woroniecka (ed.) "Co znaczy mieszkać? Szkice antropologiczne”, Warsaw: TRIO, pp. 47 -72 .

[15] Sprzedaż mieszkań z TBS zostanie uwolniona, (2015) www.prawo/money/pl/.../sprzedaz-mieszkan-z-tbs-zostanieuwolniona,239,0,1731311,html, accessed 22 June 2015.

[16] Tomczuk Jacek (2015) Oswajanie betonu. "Newsweek Polska”, no. 25, 21 June, pp. 38-40.

[17] Wielgo Marek (2015) Budowanie pod seniora, Gazeta Wyborcza, 20 May.

[18] Woroniecka Grażyna (2001) Działanie polityczne. Próba socjologii interpretatywnej. Warsaw: Oficyna Naukowa.

[19] Woroniecka Grażyna (2004) Co znaczy "mieszkać" w świecie ruchu i gloobalizacji (in:) M. Kempny, K. Kiciński, E. Zakrzewska (ed.) Od kontestacji do konsumpcji. Szkice o przeobrażeniach współczesnej kultury. Warsaw: WUW, pp. 321-332. 